\title{
Occurrence, Population Density and Biological Control of Root-Knot Nematode, Meloidogyne javanica Infecting Pomegranate Orchards in Assiut Governorate, Egypt
}

\author{
"El-Qurashi, M.A.; Aida M. I. El-Zawahry; K.M. H. Abd-El-Moneem and M.I. Hassan \\ ${ }^{1}$ Department of Plant Pathology, Faculty of Agriculture, Assiut University, Egypt \\ ${ }^{2}$ Department of Genetics, Faculty of Agriculture, Assiut University, Egypt \\ *Corresponding author: Mostafa.elqurashi@agr.au.edu.eg
}

\begin{abstract}
:
The survey conducted to assess the incidence of root-knot nematode on pomegranate in five localities (El-Badary, Manfalout, Sedfa, Sahel-Selim and ElFath) in Assiut governorate. Results showed that 490 out of 500 samples were infested with root-knot nematode showing 98\% infestation. Maximum infestation was found in El-Badary, Manfalout and El-Fath (100\%), while the minimum was observed in Sahel-Selim (94\%) followed by Sedfa (96\%). In growing season 2013 , the highest occurrence of root-knot nematode second stage was in pomegranate orchards of Sahel-Selim locality (394 J2/100 g soil), but the lowest number was found in Sedfa county (88.8 J2/100 g soil). In 2014, the highest number of juveniles per $100 \mathrm{~g}$ soil was observed in El-Fath county (275.4), whereas Manfalout county was the lowest infection (134.2). Bioagents (fungi, bacteria, yeast and actinomycetes) were isolated from pomegranate rhizosphere and evaluated against root-knot nematode J2 mortality percent in vitro. Among 29 fungal culture filtrates, the highest effect was found in culture filtrate of 3 isolates $(2,3$ and 10) with average mortality percent $8.33,10.01$ and 9.22 , respectively with nonsignificant. The fungal isolate No. 3 was selected and identified as Fusarium verticilloids. From 17 isolates of bacteria, yeast and actinomycetes, the highest mortality was observed in case of isolates No. 8, 9, 10, 11, 12, 15 and 16 with average $24.22,23.69,25.59,25.82,26.52,22.13$ and 25.24 mortality percent respectively, with nonsignificantly difference. According to morphological and physiological characteristics, isolates No. 10, 11, 12 and 16 were identified as Xenorhabdus beddingii, Streptomyces halstedii, Pantoea agglomerans and Pichia guilliermondii.
\end{abstract}

Keywords: Pomegranate, Root-knot nematode, population density, occurrence, bioagents.

\section{Introduction:}

The pomegranate (Punica granatum L.) is an ancient fruit belongs to the family Punicaceae which includes one genus and two species. It is a widely grown horticulture crop in many tropical and subtropical countries. In Egypt, pomegranate considered one of the most important fruit trees cultivated in warm regions such as Assiut province where the climate is characterized by long hot summer and low air humidity.

Most of the pomegranate cultivated areas around the world were found infested with plant-parasitic nematodes such as Jordan (Hashim, 1983), Libya (Siddiqui and Khan, 
1986), and Pakistan (Khan et al., 2005 and Khan and Shaukat, 2010).

Several of the trees showed symptoms of severe decline. These included stunting, poor vegetative growth, desiccation and defoliation of branches and yellowing of leaves (often with brown necrotic tips) as suggested by Hashim (1983).

Root-knot nematode, (RKN) which comes from Meloidogyne species is an obligate endoparasitic nematode, which can be found in varieties of plants, considered as a host to that particular nematode. Their potential host range encompasses more than 3000 plant species and they cause great agriculture loss. (Ralmi et al., 2016). It can be managed effectively by chemical treatments but many of the nematicides are expensive, pernicious to the environment and human health, so using antagonistic plants can be very attractive alternative (Mukhtar et al., 2013). Due to environmental concerns and increased regulations on use of chemical nematicides, more effective management strategies for root-knot nematodes are currently being investigated (Noling and Backer, 1994). Among the biological control agents that have been assessed are antagonistic bacteria, nematophgous fungi and yeasts (Kiewnick and Sikora, 2005 and Karajeh, 2013).

Fungal natural products are very promising potential sources of new chemicals to manage plant-parasitic nematodes (Anke and Sterner, 1997). Adverse effect of culture filtrates of several fungi on hatching and mortality of root-knot nematodes has been reported by Mankau, 1969; Shukla and Swarup, 1971; Khan et al., 1984;
Nitao et al., 1999, 2001; Meyer et al., 2004 and Sun et al., 2006).

With this background, therefore, we intend to find alternative methods to manage root-knot nematode. So this study aimed to occurrence and population density of root-knot nematode infected pomegranate orchards in five localities in Assiut governorate, isolation and manages rootknot nematode using bioagents under laboratory conditions.

\section{Material and Methods:}

\section{1- Occurrence and population} density of root-knot nematodes:

An extensive survey of rootknot nematodes associated with pomegranate orchards in Assiut governorate was undertaken during 2013 and 2014 growing seasons. A total of 500 soil and root samples were collected from five different localities (El-Badary; Manfalout; Sedfa; SahelSelim and El-Fath) in Assiut governorate (100 samples from each locality) cultivated with pomegranate (Manfalouty cv.).

\section{1-1- Sampling and Nematode extraction:}

Soil and root samples were collected by digging the soil surrounding the trees and mixed carefully. All samples were kept in polyethylene bags to prevent water drying and sent directly to the laboratory for nematode extraction and identification.

Each soil sample was carefully mixed and $100 \mathrm{~g}$ from each soil sample were successively wet-sieved through 100 and 400 mesh sieves (Goodey, 1957). The obtained suspension containing the nematodes was transferred to a Baermann pan fitted with a soft tissue paper to separate the active nematodes from the 
debris and fine soil particles. After 48 hours, nematode-water suspension was collected and concentrated to 10 $\mathrm{ml}$ in a glass vial by using a 400 mesh sieve.

Root-knot nematodes larvae, in aliquats of $1 \mathrm{ml}$ of the extracted nematode suspension, were counted by Hawksely counting slide under the research microscope.

\section{2- Nematode stock culture:}

Egg masses of Meloidogyne javanica (Treub) Chitwood, infected pomegranate roots collected from localities of El-Badary, Sahel-Selim, Sedfa, El-Fath and Manfalout counties were used to inoculate 2 weeks old healthy seedlings of tomato cv. Super Marmande. Six weeks after inoculation, plants were uprooted and examined for nematode infection and reproduction. The infected roots were used to extract nematode eggs as described by Hussey and Barker (1973).

3- Management of $M$. javanica by bioagents under laboratory conditions:

\section{Isolation of certain bioagents from pomegranate rhizosphere:}

Twenty nine isolates of fungi, twelve bacterial isolates, four yeast isolates and one actinomycete isolate were isolated from pomegranate rhizosphere of five counties (ElBadary; Manfalout; Sedfa; SahelSelim and El-Fath) in Assiut governorate.

\section{Preparation of fungal culture filtrates:}

One-week old fungi cultures on PDA plates $(100 \mathrm{~mm})$ were homogenized into potato dextrose broth (PDB) medium $1 \mathrm{~cm}$ PDA / 250 $\mathrm{ml}$ flask containing $100 \mathrm{ml}$ PDB and incubated at $25^{\circ} \mathrm{C}$ on a shaker $(240$ rpm) for 7 days. After incubation, the culture broth was centrifuged at $10,000 \mathrm{~g}$ for 10 minutes, and the supernatant passed through a $0.2 \mu \mathrm{m}$ filter. All culture filtrates were stored at $4^{\circ} \mathrm{C}$ until used (Nitao et al., 1999 and Meyer et al., 2000).

3-1- Assays of fungi culture filtrates against $M$. javanica in vitro:

Second stage juveniles of $M$. javanica were surface sterilized with $0.5 \% \mathrm{NaOCl}$ for $15 \mathrm{~s}$, washed with sterile distilled water three times and transferred to either culture filtrates of isolated fungi or sterile water, served as control ( $1 \mathrm{ml}$ of $\mathrm{J}_{2} / 10 \mathrm{ml}$ of culture filtrate). There were 29 isolates with 3 replicats and each replicat containing about $100 \mathrm{~J}_{2}$ according to Naserinasab et al., 2011 with modification. Data were recorded on $\% \mathrm{~J}_{2}$ mortality after $12,24,36$ and 48 $\mathrm{h}$ of incubation at $25 \pm 2^{\circ} \mathrm{C}$.

\section{3-2- Preparation of} bacterial, actinomycete and yeast isolates:

Cultures (48 hrs-old) grown on NS medium $(5.0 \mathrm{~g}$ peptone, $3.0 \mathrm{~g}$ beef extract, $\quad 5.0 \mathrm{~g}$ sucrose, $1000 \mathrm{ml}$ distilled water and adjusted to $\mathrm{pH} 7.0$ ) (Dowson, 1957) were centrifuged at $10,000 \mathrm{rpm}$ for $10 \mathrm{mins}$ to separate the bioagent cells. After centrifugation, supernatants were discarded and pellets were washed by centrifugation three times with sterilized distilled water (SDW) and finally suspended in SDW (AboElyousr et al., 2010). The optical density (OD) of the suspension was adjusted to $0.2(\mathrm{~A} 360 \mathrm{~nm})$ with the help of a UV-visible spectrophotometer (spectronic 20D) equivalent to $10^{5} \mathrm{CFU} / \mathrm{ml}$. This 
concentration was used for all experiments.

3-3- Assays of bacteria, actinomycete and yeasts against $M$. javanica In vitro:

Effects of bacterial, yeast and actinomycete suspentions were evaluated against $M$. javanica J2 under laboratory conditions. For this experiment, 100 freshly hatched $M$. javanica $\mathrm{J} 2$ ( $1 \mathrm{ml}$ from nematode suspention) were transferred to $10 \mathrm{~cm}$ diam Petri dishes containing $10 \mathrm{ml}$ of each (bacterial, actinomycete or yeast suspentions) $\left(10^{5} \mathrm{CFU} / \mathrm{ml}\right)$ separatly. Petri dishes maintained at $25^{\circ} \mathrm{C}$ in an incubator. Each treatment was replicated 3 times. Mortility percent of $\mathrm{J} 2$ were determined under resarch microscope at 60x magnification after $12,24,36$ and $48 \mathrm{hrs}$ of incubation. (Abo-Elyousr et al., 2010).

4- Identification of bioagents using morphological and physiological characteristics:

Identification of fungal isolate was carried out by using the morphological characteristics of mycelia and spores as described by Booth (1971) and Leslie and Summerell (2006) and confirmed by Assiut University Mycological Center (AUMC) Assiut, Egypt.

Bacteria, actinomycete and yeast were identified according to their morphological cultural and physiological charactristics as recommended by Kurtzman and Fell, (1998) for identify yeasts, Bergey's Manual of systematic Bacteriology (krieg and Holt, 1984) and Bergey's Manual of Determinative Bacteriology $9^{\text {th }}$ edition (Holt et al., 1994) for identify bacteria and actinomycetes.

\section{Results: \\ 1- Occurrence and population density of root-knot nematodes:}

A total of 500 soil and root samples were collected from pomegranate orchards in five localities in Assiut governorate (Sahel-Selim, ElBadary, Manfalout, Sedfa and ElFath). These orchards were cultivated with Manfalouty variety. Soil and root samples were collected and processed for the nematode extraction and identication.

The results of analysis of soil and root samples are given in Fig. 1 showed that, 490 out of 500 samples were infested with root-knot (R K) nematodes showing $98 \%$ infestation. Maximum samples (100\%) were found infested with the nematode in El-Badary, Manfalout and El-Fath, while minimum infestation was observed in Sahel-Selim followed by Sedfa with average percent 94 and 96 , respectively.

The occurrence and population density of second stage juveniles in $100 \mathrm{~g}$ soil was obtained and listed in Fig. 2. Data showed that, the highest occurrence of root-knot nematodes was in pomegranate orchards of Sahel-Selim locality in growing season 2013 and El-Fath locality in growing season 2014, where the average numbers of extracted juveniles from soil were 394 and $275.4 \mathrm{~J} 2 / 100 \mathrm{~g}$ soil, respectively. On the other hand, the lowest number of second stage juveniles counted in samples of Sedfa at 2013 and Manfalout localities 2014 with an average of 88.8 and 134.2 $\mathrm{J} 2 / 100 \mathrm{~g}$ soil, respectively. The average number of the second stage juveniles recovered from soil samples of El-Badary, El-Fath and Manfalout 
localities in season 2013 were 229.4 , 147.6 and 131 respectively, whereas in season 2014 of El-Badary, Sahel-
Selim and Sedfa localities were 234.4, 134.6 and $141 \mathrm{~J} 2 / 100 \mathrm{~g}$ soil, respectively.

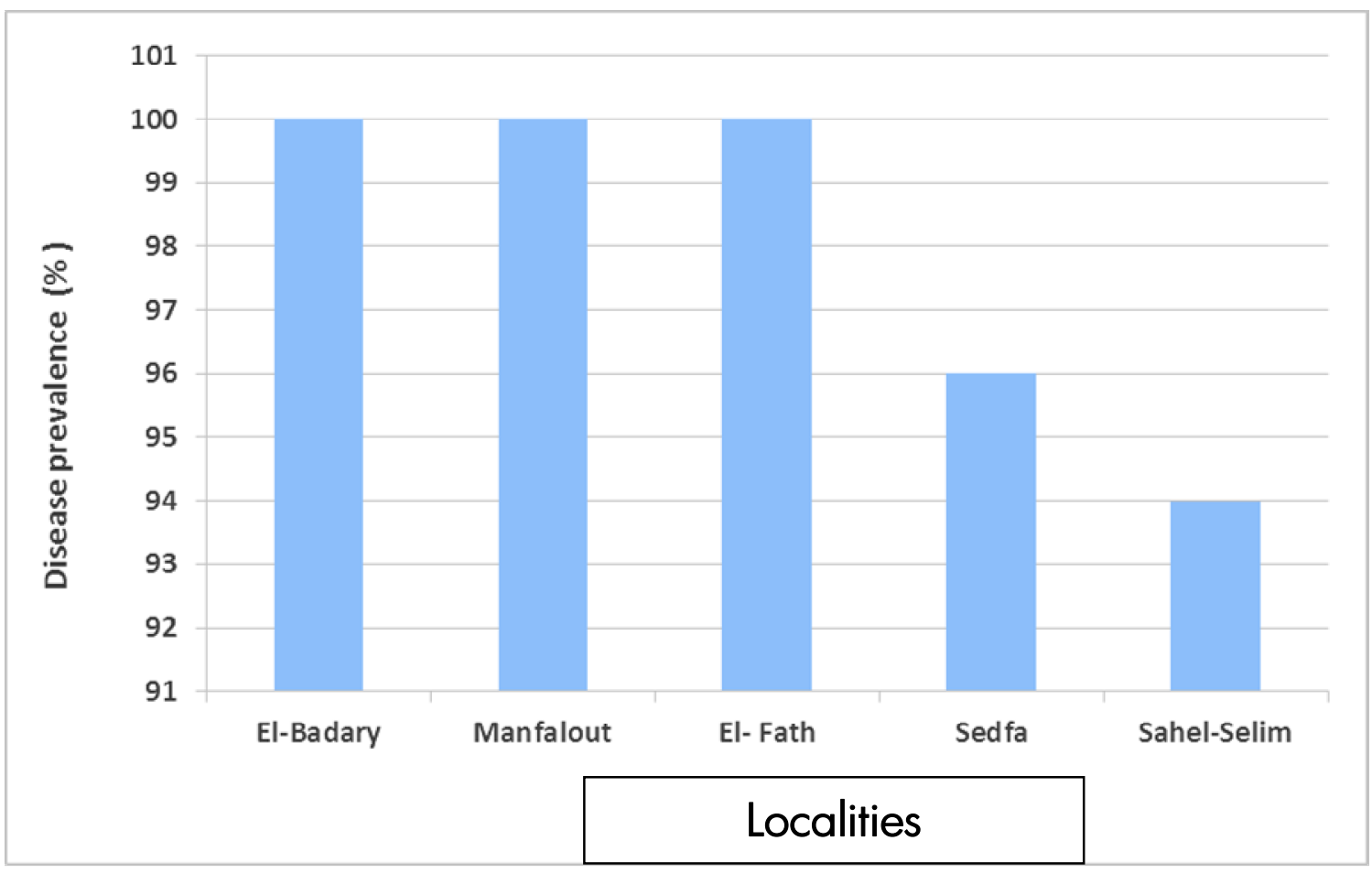

Fig (1): Prevalence of root-knot nematodes associated with Pomegranate at five localities of Assiut governorate.

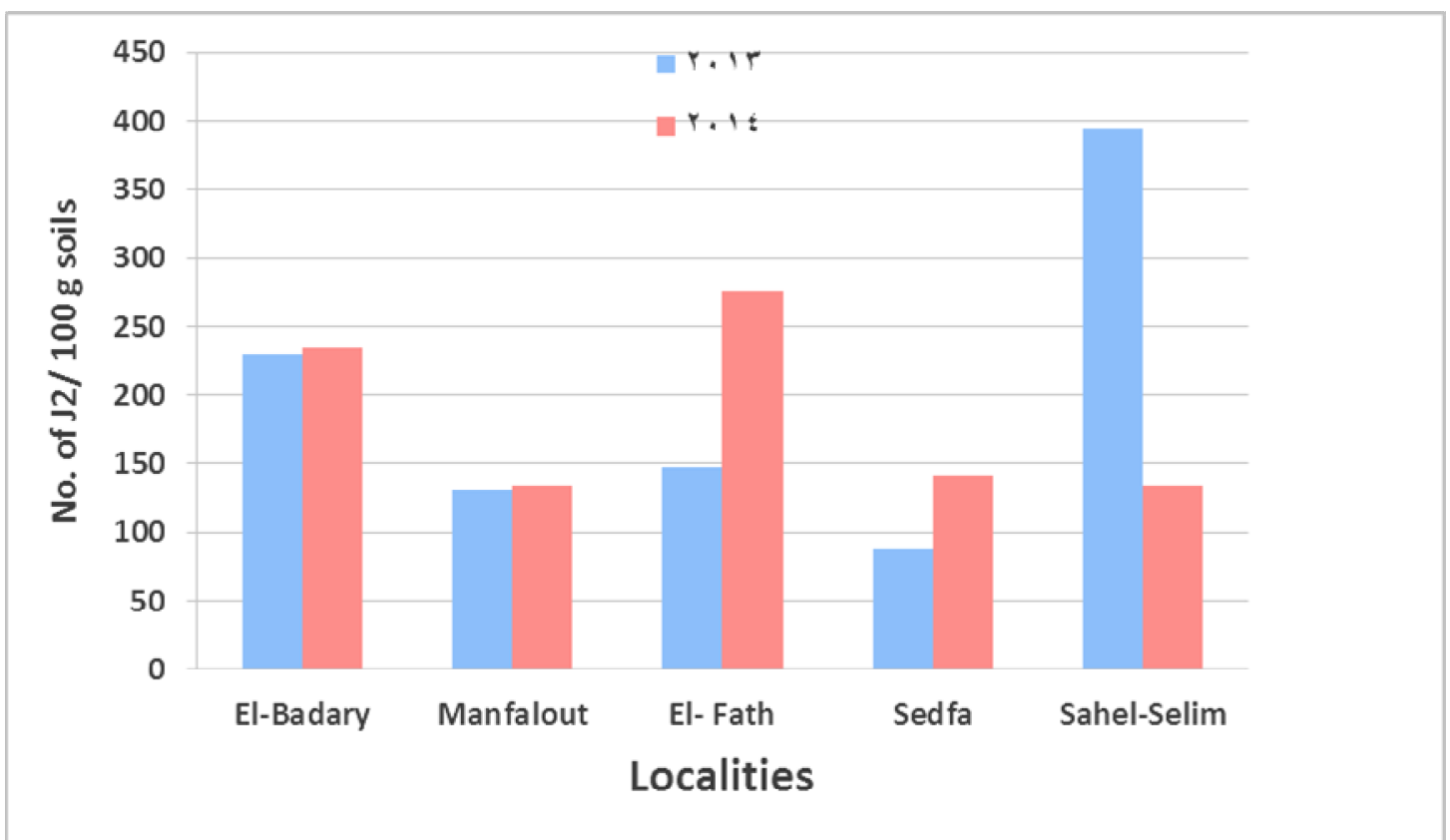

Fig (2): Population density of root-knot nematodes associated with Pomegranate orchards in Assiut governorate during 2013 and 2014 seasons. 
2- Effeciency of bioagents against $M$. javanica under laboratory conditions:

In this experiment, fungi were used as fungal culture filtrate, while bacteria, actinomycete and yeasts were used as cell suspention.

\subsection{Fungal culture filtrates:}

Twenty nine fungal isolates were isolated from pomegranate rhizosphere. Fungi were grown on PDB medium for 7 days and their culture filtrates were investigated against $M$. javanica in vitro. Data in Table (1) showed that, there were significantly differences between the isolates. Isolates No.2, 3 and 10 were the highest effect on nematode with average mortality $8.33,10.01$ and $9.22 \%$ followed by isolate No. 6 with average $6.57 \%$. The lowest mortality percent was observed in case of the rest of fungal culture filtrates compared with control.

The nematode mortality percent affected with exposure period. The highest effect of culture filtrate was found after 48 and $36 \mathrm{hrs}$ exposure with average mortality 2.28 and 2.12 , respectively, with nonsignificantly different while, the least effect was observed after 12 and $24 \mathrm{hrs}$ exposure with average mortality 0.093 and 0.75 , respectively with nonsignificantly different.

Table 1. Efficiency of certain fungal culture filtrates against $M$. javanica larvae in vitro.

\begin{tabular}{|c|c|c|c|c|c|c|}
\hline \multirow{3}{*}{ Isolate No. } & \multirow{3}{*}{ Locality } & \multicolumn{4}{|c|}{$\%$ of $\mathrm{J} 2$ mortality } & \multirow{3}{*}{ Mean } \\
\hline & & \multicolumn{4}{|c|}{ Exposure time (hours) } & \\
\hline & & 12 & 24 & 36 & 48 & \\
\hline 1 & Sedfa & $0.0^{\mathrm{G}}$ & $0.0^{\mathrm{G}}$ & $0.0^{\mathrm{G}}$ & $0.0^{\mathrm{G}}$ & $0.0^{\mathrm{C}}$ \\
\hline 2 & Sedfa & $0.0^{G}$ & $0.0^{\mathrm{G}}$ & $16.67^{\mathrm{A}}$ & $16.67^{\mathrm{A}}$ & $8.33^{\mathrm{AB}}$ \\
\hline 3 & El-Fath & $0.0^{\mathrm{G}}$ & $7.54^{\mathrm{CD}}$ & $16.24^{\mathrm{A}}$ & $16.24^{\mathrm{A}}$ & $10.01^{\mathrm{A}}$ \\
\hline 4 & El-Fath & $2.78^{\mathrm{F}}$ & $2.78^{\mathrm{F}}$ & $2.78^{\mathrm{F}}$ & $2.78^{\mathrm{F}}$ & $2.78^{C}$ \\
\hline 5 & El-Fath & $0.0^{\mathrm{G}}$ & $0.0^{\mathrm{G}}$ & $0.0^{\mathrm{G}}$ & $0.0^{\mathrm{G}}$ & $0.0^{\mathrm{C}}$ \\
\hline 6 & Sedfa & $0.0^{\mathrm{G}}$ & $6.06^{\mathrm{DE}}$ & $10.10^{\mathrm{C}}$ & $10.10^{\mathrm{C}}$ & $6.57^{\mathrm{B}}$ \\
\hline 7 & Sedfa & $0.0^{\mathrm{G}}$ & $0.0^{\mathrm{G}}$ & $0.0^{\mathrm{G}}$ & $0.0^{\mathrm{G}}$ & $0.0^{\mathrm{C}}$ \\
\hline 8 & Sedfa & $0.0^{\mathrm{G}}$ & $0.0^{\mathrm{G}}$ & $0.0^{\mathrm{G}}$ & $0.0^{\mathrm{G}}$ & $0.0^{C}$ \\
\hline 9 & El-Fath & $0.0^{\mathrm{G}}$ & $0.0^{\mathrm{G}}$ & $4.76^{\mathrm{EF}}$ & $4.76^{\mathrm{EF}}$ & $2.38^{C}$ \\
\hline 10 & Sedfa & $0.0^{\mathrm{G}}$ & $6.11^{\mathrm{DE}}$ & $12.91^{\mathrm{B}}$ & $17.85^{\mathrm{A}}$ & $9.22^{\mathrm{AB}}$ \\
\hline 11 & El-Fath & $0.0^{\mathrm{G}}$ & $0.0^{\mathrm{G}}$ & $0.0^{\mathrm{G}}$ & $0.0^{\mathrm{G}}$ & $0.0^{C}$ \\
\hline 12 & El-Fath & $0.0^{\mathrm{G}}$ & $0.0^{\mathrm{G}}$ & $0.0^{\mathrm{G}}$ & $0.0^{\mathrm{G}}$ & $0.0^{\mathrm{C}}$ \\
\hline 13 & Sedfa & $0.0^{\mathrm{G}}$ & $0.0^{\mathrm{G}}$ & $0.0^{\mathrm{G}}$ & $0.0^{\mathrm{G}}$ & $0.0^{\mathrm{C}}$ \\
\hline 14 & El-Fath & $0.0^{\mathrm{G}}$ & $0.0^{\mathrm{G}}$ & $0.0^{\mathrm{G}}$ & $0.0^{\mathrm{G}}$ & $0.0^{\mathrm{C}}$ \\
\hline 15 & Sedfa & $0.0^{\mathrm{G}}$ & $0.0^{\mathrm{G}}$ & $0.0^{\mathrm{G}}$ & $0.0^{\mathrm{G}}$ & $0.0^{\mathrm{C}}$ \\
\hline 16 & El-Fath & $0.0^{\mathrm{G}}$ & $0.0^{\mathrm{G}}$ & $0.0^{\mathrm{G}}$ & $0.0^{\mathrm{G}}$ & $0.0^{\mathrm{C}}$ \\
\hline 17 & El-Badary & $0.0^{\mathrm{G}}$ & $0.0^{\mathrm{G}}$ & $0.0^{\mathrm{G}}$ & $0.0^{\mathrm{G}}$ & $0.0^{\mathrm{C}}$ \\
\hline 18 & Manfalout & $0.0^{\mathrm{G}}$ & $0.0^{\mathrm{G}}$ & $0.0^{\mathrm{G}}$ & $0.0^{\mathrm{G}}$ & $0.0^{\mathrm{C}}$ \\
\hline 19 & Manfalout & $0.0^{\mathrm{G}}$ & $0.0^{\mathrm{G}}$ & $0.0^{\mathrm{G}}$ & $0.0^{\mathrm{G}}$ & $0.0^{\mathrm{C}}$ \\
\hline 20 & Sahel-Selim & $0.0^{\mathrm{G}}$ & $0.0^{\mathrm{G}}$ & $0.0^{\mathrm{G}}$ & $0.0^{\mathrm{G}}$ & $0.0^{\mathrm{C}}$ \\
\hline 21 & Manfalout & $0.0^{\mathrm{G}}$ & $0.0^{\mathrm{G}}$ & $0.0^{\mathrm{G}}$ & $0.0^{\mathrm{G}}$ & $0.0^{\mathrm{C}}$ \\
\hline 22 & Sahel-Selim & $0.0^{\mathrm{G}}$ & $0.0^{\mathrm{G}}$ & $0.0^{\mathrm{G}}$ & $0.0^{\mathrm{G}}$ & $0.0^{\mathrm{C}}$ \\
\hline 23 & Manfalout & $0.0^{\mathrm{G}}$ & $0.0^{\mathrm{G}}$ & $0.0^{\mathrm{G}}$ & $0.0^{G}$ & $0.0^{\mathrm{C}}$ \\
\hline 24 & El-Badary & $0.0^{\mathrm{G}}$ & $0.0^{\mathrm{G}}$ & $0.0^{\mathrm{G}}$ & $0.0^{\mathrm{G}}$ & $0.0^{\mathrm{C}}$ \\
\hline 25 & Sahel-Selim & $0.0^{\mathrm{G}}$ & $0.0^{\mathrm{G}}$ & $0.0^{\mathrm{G}}$ & $0.0^{\mathrm{G}}$ & $0.0^{\mathrm{C}}$ \\
\hline 26 & Sahel-Selim & $0.0^{\mathrm{G}}$ & $0.0^{\mathrm{G}}$ & $0.0^{\mathrm{G}}$ & $0.0^{\mathrm{G}}$ & $0.0^{\mathrm{C}}$ \\
\hline 27 & El-Badary & $0.0^{\mathrm{G}}$ & $0.0^{\mathrm{G}}$ & $0.0^{\mathrm{G}}$ & $0.0^{\mathrm{G}}$ & $0.0^{\mathrm{C}}$ \\
\hline 28 & Manfalout & $0.0^{G}$ & $0.0^{\mathrm{G}}$ & $0.0^{G}$ & $0.0^{G}$ & $0.0^{\mathrm{C}}$ \\
\hline 29 & El-Badary & $0.0^{\mathrm{G}}$ & $0.0^{\mathrm{G}}$ & $0.0^{\mathrm{G}}$ & $0.0^{\mathrm{G}}$ & $0.0^{\mathrm{C}}$ \\
\hline \multicolumn{2}{|c|}{ Control } & $0.0^{\mathrm{G}}$ & $0.0^{\mathrm{G}}$ & $0.0^{\mathrm{G}}$ & $0.0^{\mathrm{G}}$ & $0.0^{\mathrm{C}}$ \\
\hline \multicolumn{2}{|c|}{ Mean } & $0.093^{B}$ & $0.75^{\mathrm{B}}$ & $2.12^{A}$ & $2.28^{\mathrm{A}}$ & \\
\hline
\end{tabular}

LSD value at $5 \%$ :

Isolates $(A)=3.253 \quad$ Time $(B)=0.8012$

$\mathrm{AB}=2.741$ 
Bacteria, actinomycete and yeast:

Effects of certain bacteria, actinomycete and yeast on root-knot nematode, $M$. javanica larvae activity were investigated under laboratory conditions. Some antagonistic isolates were found with high effect on nematode, while the others were the least effect compared to the control.

Data in Table 2 showed that, there were a significantly differences between the tested antagonistic isolates on $\mathrm{J} 2 \%$ mortality, the highest percent of mortality was observed in case of isolates No. 8, 9, 10, 11, 12, 15 and 16 with average mortality (24.22, 23.69, 25.59, 25.82, 26.52,
22.13 and 25.24), respectively followed by isolates No. 1 (15.95), 3 (14.94), 4 (12.19), 5 (8.74), 6 (11.34), 7 (11.35), 13 (16.61), 14 (11.89) and 17 (14.62).

Data also concluded that, the mortality of nematode was attributed to the exposure periods. There were significant differentiations between the exposure periods, where the nematode exposure to $48 \mathrm{hrs}$ obtained the highest mortality, followed by 36 hrs with average percent 24.65 and 19.55, respectively, while, $12 \mathrm{hrs}$ was the least effect and then $24 \mathrm{hrs}$ with average percent 9.643 and 14.28 , respectively, compared to the control.

Table 2. Efficiency of certain bacterial, actinomycete and yeast isolates against $M$. javanica larvae in vitro.

\begin{tabular}{|c|c|c|c|c|c|c|c|}
\hline \multirow{3}{*}{$\begin{array}{l}\text { Isolate } \\
\text { No. }\end{array}$} & \multirow{3}{*}{ County } & \multirow{3}{*}{ Category } & \multirow{2}{*}{\multicolumn{4}{|c|}{$\begin{array}{c}\% \text { of } \mathrm{J} 2 \text { mortality } \\
\text { Exposure period (hours) }\end{array}$}} & \multirow{3}{*}{ Mean } \\
\hline & & & & & & & \\
\hline & & & 12 & 24 & 36 & 48 & \\
\hline 1 & El-Badary & Bacteria & 12.50 & 14.24 & 17.22 & 19.85 & $15.95^{\mathrm{CDE}}$ \\
\hline 2 & El-Badary & Yeast & 6.857 & 8.207 & 9.40 & 10.85 & $8.828^{\mathrm{EF}}$ \\
\hline 3 & El-Badary & Bacteria & 9.077 & 12.89 & 14.48 & 23.31 & $14.94^{\mathrm{DE}}$ \\
\hline 4 & El-Badary & Yeast & 7.737 & 12.29 & 11.28 & 17.48 & $12.19^{\mathrm{EF}}$ \\
\hline 5 & El-Badary & Bacteria & 4.487 & 7.503 & 10.22 & 12.73 & $8.737^{\mathrm{EF}}$ \\
\hline 6 & El-Badary & Yeast & 9.49 & 10.12 & 10.81 & 14.94 & $11.34^{\mathrm{EF}}$ \\
\hline 7 & El-Fath & Bacteria & 8.047 & 11.33 & 12.36 & 13.67 & $11.35^{\mathrm{EF}}$ \\
\hline 8 & El-Fath & Bacteria & 14.88 & 21.18 & 28.90 & 31.90 & $24.22^{\mathrm{AB}}$ \\
\hline 9 & Manfalout & Bacteria & 5.293 & 15.47 & 30 & 43.98 & $23.69^{\mathrm{ABC}}$ \\
\hline 10 & Manfalout & Bacteria & 21.59 & 23.64 & 27.44 & 29.70 & $25.59^{A}$ \\
\hline 11 & Manfalout & Actinomycetes & 19.22 & 23.47 & 27.72 & 32.87 & $25.82^{A}$ \\
\hline 12 & Sahel- Selim & Bacteria & 11.63 & 18.83 & 27.93 & 47.68 & $26.52^{A}$ \\
\hline 13 & Sahel-Selim & Bacteria & 8.513 & 10.55 & 23.42 & 23.96 & $16.61^{\mathrm{BCDE}}$ \\
\hline 14 & Sedfa & Bacteria & 3.03 & 12.86 & 14.25 & 17.41 & $11.89^{\mathrm{EF}}$ \\
\hline 15 & Sedfa & Bacteria & 9.47 & 21.93 & 25.70 & 31.42 & $22.13^{\mathrm{ABCD}}$ \\
\hline 16 & Sedfa & Yeast & 15.25 & 18.71 & 28.96 & 38.03 & $25.24^{A}$ \\
\hline 17 & Sedfa & Bacteria & 2.777 & 8.64 & 23.73 & 23.33 & $14.62^{\text {DEF }}$ \\
\hline & Contre & & 3.723 & 5.163 & 8.077 & 10.67 & $6.908^{F}$ \\
\hline & Mean & & $9.643^{D}$ & $14.28^{C}$ & $19.55^{B}$ & $24.65^{A}$ & \\
\hline
\end{tabular}

LSD value at 0.05 :

Isolates $(\mathrm{A})=8.027$

Time $(\mathrm{B})=2.48$

Interaction $(\mathrm{AB})=6.638$ 


\subsection{Identification of bioagents using morphological and physiological characteristics:}

Identification of highest antagonistic isolates of bacteria, actinomycetes and yeast isolates were carried out using the morphological and physiological characteristics.

Identification fungus isolate (No. 3) was revealed to Fusarium verticilliodes based on the morphological feature of mycelia and spores as described by Booth (1971) and confirmed by the Assiut University, Mycological Center (AUMC).

On the basis of the obtained data and those reported by Krieg and Holt (1984) and Holt et al. (1994), it could stated that, all tested isolates (bacteria and actinomycetes) were identified as following, Bacterial isolate No. 10 was identified as Xenorhabdus beddingii and isolate No. 12 was identified as Pantoea agglomerans While, actinomycete isolate No. 11 was identified as Streptomyces halstedii,.

According to Kurtzman and Fell (1998) to describe yeast isolate No. 16 was identified as Pichia guilliermondii.

\section{Discussion:}

The present survey confirms the occurrence of root-knot nematodes (Meloidogyne spp.) associated with pomegranate orchards in Assiut governorate. The results of analysis of soil and root samples collected from pomegranate orchards in five different localities (Sahel-Selim, ElBadary, El-Fath, Sedfa and Manfalout) showed that, 490 out of 500 samples were infested with root-knot nematodes showing 98\% infestation.
Maximum samples (100\%) infested with root-knot nematodes were found in El-badary, El-Fath and Manfalout, while minimum infestation (94\%) was observed in Sahel-Selim. Rootknot nematodes were reported by several investigators as an important nematode pest attacking pomegranate orchards in different countries, (Hashim, 1983) in Jordan, Siddiqui and Khan (1986) in Libya, Khan et al., (2005) and Khan and Shaukat (2010) in Pakistan.

The effect of fungal culture filtrates were examined against $M$. javanica under laboratory conditions, Fusarium verticilliodes culture filtrate was the highest in $M$. javanica mortality percent.

Culture filtrates of many fungi possess activity against nematodes and the nematicidal action of these culture filtrates may involve the production of toxic metabolites by the fungi (Caroppo et al., 1990; Singh et al., 1991; Hallmann and Sikora, 1996; Nitao et al., 1999; Kusano et al., 2000, 2003; Nakahara et al., 2004; Kanai et al., 2004; Heydari et al., 2006; Hayashi et al., 2007; Liu et al., 2008; Du et al., 2009).

Fungal natural products are very promising potential sources of new chemicals to manage plant-parasitic nematodes (Anke and Sterner, 1997).

Species of Aspergillius, Penicillium, Trichoderma, Fusarium, Paecilomyces and Alternaria are known to produce toxins and antibiotics like aflatoxins, pencillin, virdin, fusaric acid, lilacin and phyto-alternarin (Nafe-Roth, 1972; Arai et al., 1973; Wheeler, 1975; Ghewande et al., 1984). Adverse effect of culture filtrates of several fungi on hatching 
and mortality of root-knot nematodes has been reported by Mankau, 1969; Shukla and Swarup, 1971; Khan et al., 1984; Nitao et al., 1999, 2001; Meyer et al., 2004; Sun et al., 2006).

Few investegations of the effect of Fusarium toxins on plant parasitic nematodes have been reported, Mani and Sethi (1984) working with culture filtrates of $F$. solani reported reductions in hatch and mobility of $M$. incognita. Fattah and Webster (1983) observed inhibited development of $M$. javanica in roots colonized by $F$. oxysporum f. sp. Lycopersici.

In vitro assay, the effect of bacterial isolates, Actinomycetes and yeasts that isolated from pomegranate rhizosphere was examined against $\mathrm{J} 2$ $\%$ of $M$. javanica. The results showed that, the highest mortality percent was observed in treated with Pantoea agglomerans (26.52), Streptomyces halstedii (25.82), Xenorhabdus beddingii (25.59) and Pichia guilliermondii (25.24) with nonsignificantly differences. Several reports noted that suppression of Meloidogyne sp. by different rhizobacteria like Pseudomonas fluorescens (Siddiqui and Mahmood, 1999; Siddiqui et al., 2001; Hashem and Abo-Elyousr, 2011), Bacillus sp. (Siddiqui and Mahmood, 1999; Giannakou et al., 2007), Rhizobium sp. (Akhtar and Siddiqui, 2008), but no studies have not been performed on the biological control of this pathogen with $P$. agglomerans and $X$. beddingii. P. agglomerans (Cook and Baker, 1983). While, Vasebi et al. (2015) reported that there a biocontrol agent used against other plant pathogens.

A large number of soil microorganisms are capable of producing siderophores (Misaghi et al., 1988). The high ability of $P$. agglomerans in siderophore production in CAS-agar medium has been confirming that, this group of bacteria has evolved high-affinity iron uptake systems to shuttle iron into the cell.

$P$. guilliermondii is seemed to promising biocontrol agent. Although we couldn't define the exact mechanism of disease protection by this strain, it could be hypothesized that the reduction of the disease might be attributed to direct effect of metabolites that induce mortality in $\mathrm{J} 2$, or that may have also enhanced host defense mechanism in roots that resist invation and consequent infection by pathogen (Hashem et al., 2008; Hashem and Abo-Elyousr, 2011).

Saccharomyces serevisiae is promising plant growth-promoting for different crops as descriped by Karajeh (2013). S. cerevisiae was investigated as a biocontrol agent against root-knot nematode by Noweer and Hasabo (2005); Karajeh (2013) and Mokbel and Alharbi (2014). They showed that, the yeast was reduced root gall formation, egg masses and nematode reproduction ability and inhanced plant growth and fruit yield. High content of total phenolic and hydrogen peroxide in roots of $S$. cerevisiae- treated plants gives a clue on the ability of the yeast to induced plant resistance (Karajeh, 2013).

The management of root-knot nematode by Streptomyces sp. was mentioned by a lot of investigators. The actinomycetes enhanced the plant growth, imporoved fruit yield and suppressed root-gall development (Jonathan, 2000; Rajeswari and 
Ramakrishnan, 2015). Culture filtrates of actinomycetes exhibited variable response against egg hatchability and mortality of root-knot nematode (Helal et al., 2016).

The culture filtrate of the optimized medium of Streptomyces fradiae resulted in higher degree of inhibition in egg hatching and $\mathrm{J} 2$ mortality of $M$. incognita. The effectiveness of optimized medium against $M$. incognita is related to higher production of secondary metabolites subsequent to maximization of colonization (Rajeswari and Ramakrishnan, 2015).

\section{References:}

Abo-Elyousr, K. A.; Z. Khan; M. E. Award and M. F. Abedel-Moneim (2010). Evaluation of plant extracts and Pseudomonas spp. for control of root-knot nematode, Meloidogyne incognita on tomato. Nematropica, 40 (2): 289- 299.

Akhtar, M. S. and Z. A. Siddiqui (2008). Biocontrol of a root-rot disease complex of chickpea by Glomus intraradices, Rhizobium sp. and Pseudomonas straita. Crop Protection, 27: 410- 417.

Anke, H. and O. Sterner (1997). Nematicidal metabolites from higher fungi. Curr. Org. Chem., 1: 361374.

Arai, T.; Y. Mikamy; K. Fukushima; T. Utsumi and K. Kazawa (1973). A new antibiotic, leucostatin, derived from Pencillium lilacinum. J. Anitibiol. Tokyo, 26: 157-61.

Booth, C. (1971). Fungal Culture Media. In: Methods in Mcirobiology Booth, C. (Eds). (Academic Press; London), 4: 67.

Caroppo, S.; B. Perito and O. Pelagatti (1990). In vitro evaluation of nematicidal activity by several fungi against Meloidogyne incognita eggs. Redia, 73: 451-462.
Cook, R. J. and K. F. Baker (1983). The nature and practice of biological control of plant pathogens. APS, St. Paul, MN, p. 539.

Dowson, W. J. (1957). Plant disease due to bacteria, second edition Cambridge University Press.

Du, L.; D. Li; T. Zhu; S. Cai; F. Wang; X. Xiao and Q. Gu (2009). New alkaloids and diterpenes from a deep ocean sediment derived fungus Penicillium sp. tetrahedron, 65 (5): 1033- 1039.

Fattah, F. and J. M. Webster (1983). Ultrastructural changes caused by $F$. oxysporum f.sp. lycopersici in $M$. javanica induced giant cells in Fusarium resistant and susceptible tomato cultivars. Journal of Nematology, 15: 128-135.

Ghewande, M. P.; R. N. Pandey; A. K. Shukla and D.P. Mishra (1984). Toxicity of culture filtrates of $A s$ pergillus flavus on germination of seeds and seedlings growth of groundnut. Ind. Bot. Rep., 3: 10711.

Giannakou, I. O.; I. A. Anastasiadis; S. R. Gowen and D. A. ProphetouAthanasiadou (2007). Effects of a non-chemical nematicide combined with soil solarization for the control of root-knot nematodes. Crop Protection, 26: 1644- 1654.

Goodey, J. B. (1957). Laboratory methods for work with plant and soil nematodes. Tech. Bull. No. 2 Minist. Agric. London, H. M. S. O., pp. 47.

Hallmann, J. and R. A. Sikora (1996). Toxicity of fungal endophyte secandery metabolites to plant parasitic nematodes and soil-borne plant pathogenic fungi. Eur. J. Plant Pathol., 102: 155- 162.

Hashem, M. and K. A. Abo-Elyousr (2011). Management of the rootknot nematode Meloidogyne incognita on tomato with combina- 
tion of different biocontrol organisms. Crop Protection, 30: 285292.

Hashem, M.; Y. A. M. M. Omran and Nashwa M. Sallam (2008). Management of root-knot nematode Meloidogyne incognita as well as productivity of seedless grapevines via application of certain yeast strains. Biol. Cont. Sci. Technol. 18: 357-375.

Hashim, Z. (1983). Plant parasitic nematodes associated with pomegranate (Punica granatum L.) in Jordan and an attempt to chemical control. Nematol. Medit., 11: 199- 200.

Hayashi, A.; S. Fujioka; M. Nukina; T. Kawano; A. Shimada and Y. Kimura (2007). Fumiquinones $A$ and $\mathrm{B}$, nematicidal quinines produced by Aspergillus fumigatus. Biosci. Biotecnol. Biochem., 71 (7): 16971702.

Helal, M.; B. M. Refaat; G. A. Abd ElRahman and A. A. Kobisi (2016). Evaluating the nematicidal activity of soil actinomycetes against the root knot nematode, Meloidogyne incognita. Egyption J. of Biological Pest Control, 26 (3): 567- 572.

Heydari, R.; E. Pourjam and E. M. Goltapeh (2006). Antagonistic effect of some species of Pleurotus on the root-knot nematode, Meloidogyne javanic in vitro. Plant Pathol. J., 5 (2): 173- 177.

Holt, J. G.; N. R. Krieg; P. H. A. Sneathm; J. T. Staley and S. T. Williams (1994). Bergey's manual of determination bacteriology. $9^{\text {th }}$ eds. Williams and wilking, Baltimore, Maryland, U.S.A. 787pp.

Hussey, B. S. and K. R. Barker (1973). A comparison of methods of collecting inocula of Meloidogyne spp. including a new technique. Plant Dis., 57: 1025-1028.

Jonathan, E. I.; K. R. Barker; F. F. Abdel- Alim; T. C. Vrain and D. W.
Dickson (2000). Biological control of Meloidogyne incognita on tomato and banana with rhizobacteria, actinomycetes, and Pasteuria penetrans. Nematropica, 30 (2): 231- 240.

Kanai, Y.; T. Fujimaki; S. Kochi; H. Konno; S. Kanazawa and S. Tokamasu (2004). Paeciloxazine, a novel nematicidal antibiotic from Paecilomyces sp. J. Antibiot., 57: 24- 28.

Karajeh, M. R. (2013). Efficacy of Saccharomyces cerevisiae on controlling the root-knot nematode (Meloidogyne javanica) infection and promoting cucumber growth and yield under laboratory and field conditions. Archives of Phytopathology and Plant Protection, 46 (20): 2492-2500.

Khan, A. and S. S. Shaukat (2010). An analysis of phytonematode associated with pomegranate in Khuzdar and Kalat district, Balochistan. Pakistan J. Agric. Res., 23(3-4): 147- 150.

Khan, A.; S. S. Shaukat and I. A. Siddiqui (2005). A survey of nematodes of pomegranate orchards in Balochistan province, Pakistan. Nematol. Medit., 33: 25- 28.

Khan, T. A.; M. F. Azam and S. I. Hussain (1984). Effect of fungal filtrates of A. niger and Rhizoctonia solani on penetration and development of root-knot nematode and plant growth of tomato var. Marglobe. Ind. J. Nematol., 14: 106109.

Kiewnick, S. and R. A. Sikora (2005). Biological control of root-knot nematode Meloidogyne incognita by Paecilomyces lilacinus strain 251. Biol. Control, 38:179-187.

Krieg, N. R. and J. G. Holt (1984). Bergey's Manual of Systematic Bacteriology Vol. 1, Williams and Wil- 
kinc Company, Baltimore Md., U.S.A., 469 pp.

Kurtzman, C. P. and J. W. Fell (1998). The yeasts: a taxonomic study. $4^{\text {th }}$ edn, Elsevier, London, pp. 273352.

Kusano, M.; H. Koshino; J. Uzawa; S. Fujioka; T. Kawano and Y. Kimura (2000). Nematicidal alkaloids and related compounds produced by the fungus Penicillium cf. simplicissimum. Bioscience, Biotechnology, and Biochemistry, 64 (12): 2559- 2568.

Kusano, M.; K. Nakagami; S. Fujioka; T. Kawano; A. Shimada and Y. Kimura (2003). Bydehydrocurvularin and related compounds as nematicides of Pratylenchus penetrans from the fungus Aspergillus sp. Bioscience, Biotechnology, and Biochemistry, 67 (6): 1413-1416.

Leslie, J. F. and B. A. Summerell (2006). The Fusarium Laboratory Manual, Wiley Blackwell Publishing, p.388.

Liu, T.; L. Wang; Y. Duan and X. Wang (2008). Nematicidal activity of culture filtrate of Beauveria bassiana against Meloidogyne hapla. World J. Microbiol. Biotechnol., 24(1): 113-118.

Mani, A. and C. L. Sethi (1984). Some characteristics of culture filtrate of $F$. solani toxic to $M$. incognita. Nematropica, 14: 121-129.

Mankau, R. (1969). Nematicidal activity of Aspergitlus niger culture filtrates. Phytophathol., 59: 1170.

Meyer, Susan L. F.; R. N. Huettel and X. Z. Liu (2004). Activity of fungal culture filtrates against soybean cyst nematode and root-knot nematode egg hatch and juvenile motility. Nematology, 6(1): 23-32.

Meyer, Susan L. F.; Samia, I. Massoud; D. J. Chitwood and D. P. Roberts (2000). Evaluation of Trichoderma virens and Burkholderia cepacia for antagonistic activity against root-knot nematode, Meloidogyne incognita. Nematology, 2 (8): 871879.

Misaghi, I. J.; M. W. Olsen; P. J. Cotty and C. R. Donndelinger (1988). Fluorescent siderophore mediated iron deprivation a contingent biological control mechanism. Soil Biology \& Biochemistry, 20: 573574.

Mokbel, Asmaa A. and Asmaa A. Alharbi (2014). Suppressive effect of some microbial agents on rootknot nematode, Meloidogyne javanica infected eggplant. Australian J. of Crop Science, 8 (10): 1428- 1434.

Mukhtar, T.; M. Z. Kayani and M. A. Hussain (2013). Nematicidal activities of Cannabis sativa L. and Zanthoxylum alatum Roxb. against Meloidogyne incognita. Industrial Crops and Products, 42:447-453.

Nafe-Roth, S. (1972). Production and bioassay of phytotoxins. In: Phytotoxins in Plant Diseases. Wood, R.S.K., A. Ballio and A.Granite (eds.). Academic Press, New York.

Nakahara, S.; M. Kusano; S. Fujioka; A. Shimada and Y. Kimura (2004). Penipartynolene, a novel nematicide from Penicillium bilaiae chalabuda. Bioscience, Biotechnology, and Biochemistry, 68 (1): 257- 259 .

Naserinasab, Fatemeh; N. Sahebani and H. R. Etebarian (2011). Biological control of Meloidogyne javanica by Trichderma harzianum B1 and salicylic acid on tomato. African Journal of Food Science, 5 (3): 276-280.

Nitao, J. K.; Susan L. F. Meyer and D. J. Chitwood (1999). In-vitro assays of Meloidogyne incognita and Heterodera glycines for detection of nematode-antagonistic fungal 
compounds. Journal of Nematology, 31(2): 172-183.

Nitao, J. K.; Susan L. F. Meyer; W. F. Schmidt; J. C. Fettinger and D. J. Chitwood (2001). Nematodeantagonistic trichothecenes from Fusarium equiseti. J. Chem. Ecol., 27(5): 859-869.

Noling, J. W. and J. O. Backer (1994). The challenge of research and extension to difine and implement alternatives to methyl bromide. J. Nematol. 26: 573-586.

Noweer, E. M. A. and Susan A. A. Hasabo (2005). Effect of different management practices for controlling root-knot nematode Meloidogyne incognita on squash. Egypt J. Phytopathol., 33 (2): 73- 81.

Rajeswari, M. and S. Ramakrishnan (2015). Influence of Streptomyces fradiae against root knot nematode Meloidogyne incognita in tomato. Research Journal of Agriculture and Forestry Sciences, 3(1): 6- 11.

Ralmi, N. H. A.; M. M. Khandaker and N. Mat (2016). Occurrence and control of root-knot nematode in crops: a review. Australian Journal of Crop Science, 10(12):16491654.

Shukla, V.N. and G. Swarup (1971). Studies on root knot of vegetables.IV. Effects of Sclerotium rolfsii filtrate on Meloidogyne incognita. Indian J. Nematol., 1: 52-58.

Siddiqui, Z. A.; A. Iqbal and I. Mahmood (2001). Effect of Pseudomonas fluorescens and fertilizers on the reproduction of Meloidogyne incognita and growth of tomato. Applied Soil Ecology, 16: 179185.

Siddiqui, Z. A. and I. Mahmood (1999). Role of bacteria in the management of plant parasitic nematodes: a review. Bioresource Technology, 69: 167- 179.

Siddiqui, Z. A. and M. W. Khan (1986). A survey of nematodes associated with pomegranate in Libya and evaluation of some systemic nematodes for their control. Pak. J. Nematol., 4 (2): 83- 90.

Singh, S. B.; J. L. Smith; G. S. Sabnis; A. W. Dombrowski; J. M. Schaeffer; M. A. Goetz and G. F. Bills (1991). Structure and congormation of ophiobolin $\mathrm{k}$ and 6-epiphiobolin k from Aspergillus ustus as a nematicidal agent. Tetrahedron, 47: 6931- 6938.

Sun, M.; L. Gao; Y. Shi; B. Li and X. Liu (2006). Fungi and actinomycetes associated with Meloidogyne spp. eggs and females in China and their biocontrol potential. J. Invertebr. Pathol., 93(1): 22-28.

Vasebi, Y.; A. Alizadeh and N. Safaie (2015). Pantoea agglomerans as a biocontrol agent of Macrophomina phaseolina and growth enhancer of soybean. J. Crop. Prot., 4 (1): 4357.

Wheeler, H. (1975). Plant Pathogens. Springer-Verlag Berlin. Heidleberg, New York. p. 106. 


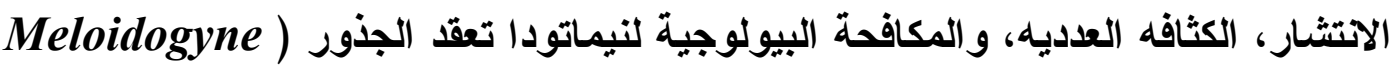
(javanica

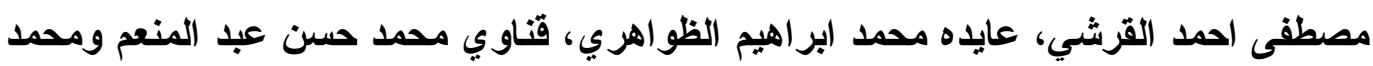

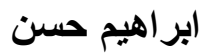

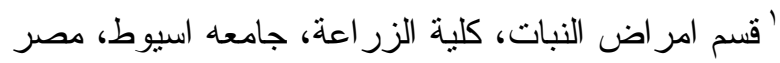

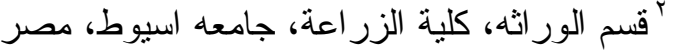

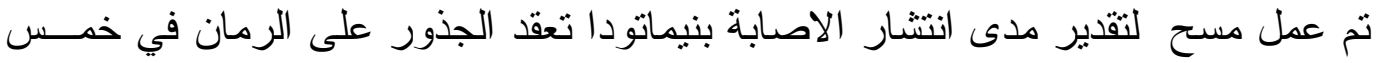

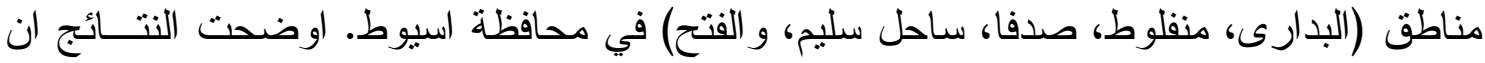

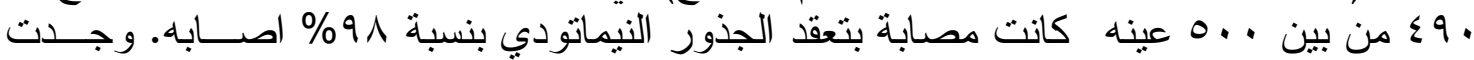

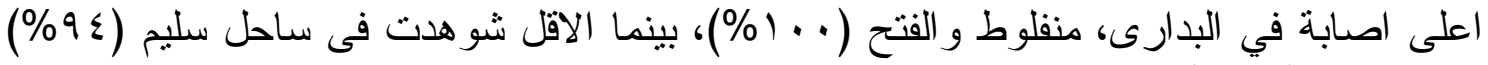

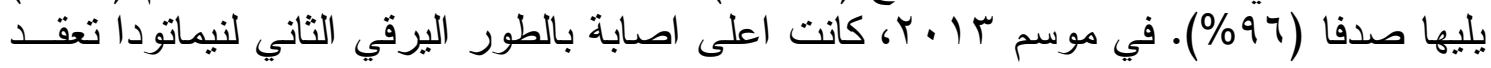

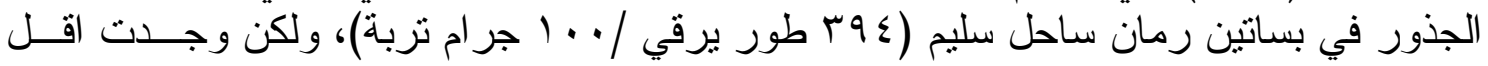

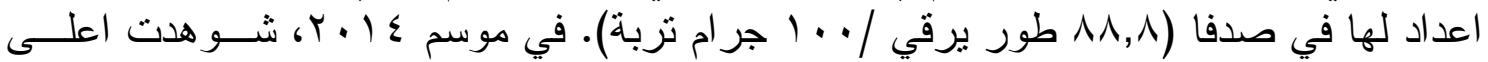

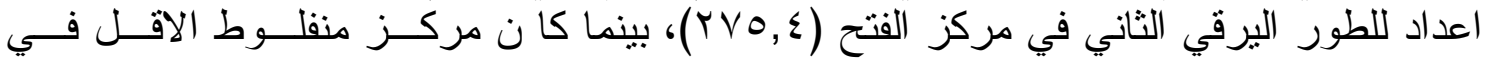

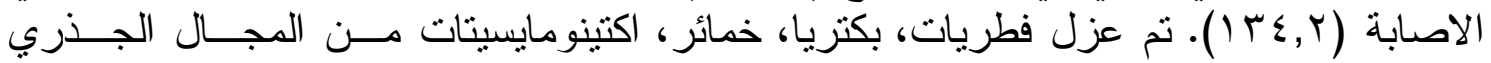

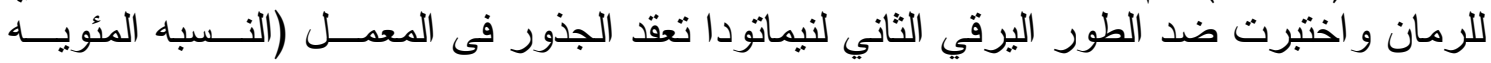

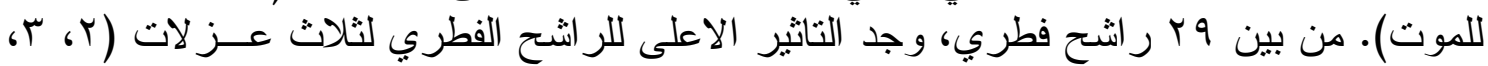

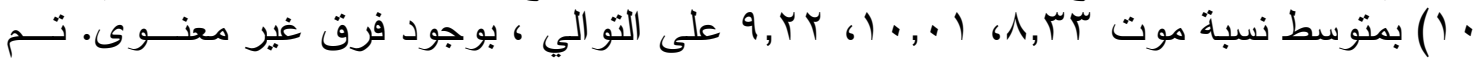

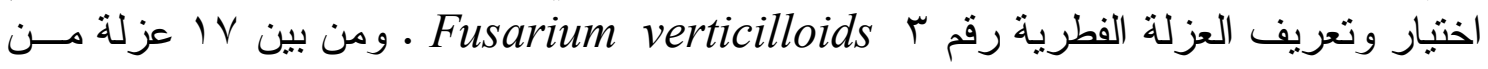

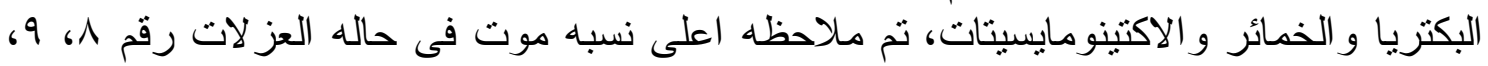

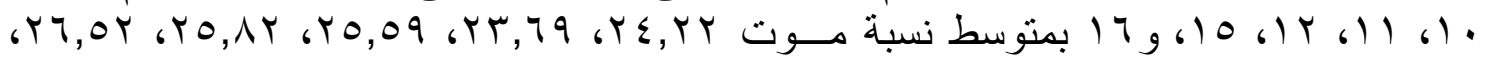

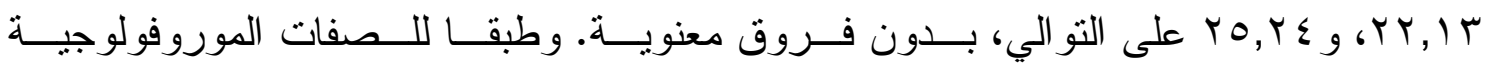

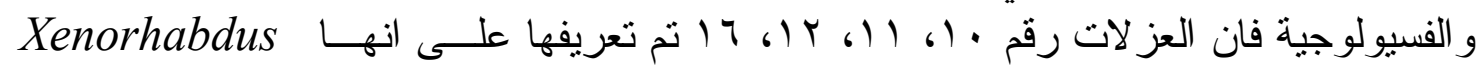
Pichia gbeddingi, Streptomyces halstedii, Pantoea agglomerans guilliermondii 